\title{
A pre-disciplinary approach to built environments education: Teaching Seattle on foot
}

Daniel E. Coslett, University of Washington, USA

James Thompson, University of Washington, USA

Keywords: Pedagogy, Pre-disciplinarity, Built environments, City, Walking, Seattle

Abstract: Educators increasingly pursue inter- and transdisciplinary pedagogies to facilitate a more holistic approach to the design, use, and interpretation of built environments. Through the presentation of one particular example of such efforts-an introductory, mixed qualitative methods, undergraduate course - this article explores three pedagogical principles central to its integrated approach: pre-disciplinarity, experiential and place-based learning, and instructional scaffolding. The course cultivates awareness of overlapping transdisciplinary themes of contemporary relevance beyond its immediate context, incorporating traditional lectures, curated city walks, small group discussion sessions, and a series of written reflections. Following a brief description of the class's content and its successful implementation, the article demonstrates how such courses can yield meaningful experiences that promote critical engagement with the city and desirable lifelong learning for future design professionals and others.

\section{Introduction: Built Environments Education in the 21st Century}

The correlation between rapid urban development and contemporary, globally significant challenges increasingly demands the fundamental reevaluation of how built environments are conceived, produced, managed, and interpreted. ${ }^{1}$ As cities are more comprehensively understood to be complex webs of activity and meaning, the inadequacy of traditional disciplinary educational practices and perspectives in addressing the multifaceted challenges facing the world becomes ever more apparent. ${ }^{2}$ Within the allied professions tasked with carrying out and improving the

\footnotetext{
${ }^{1}$ For example, many have acknowledged the role architecture can play in mitigating significant contemporary crises. See Sean Anderson, "How Architecture Can Redefine the Migrant Crisis," CNN Style, 18 May 2016, accessed 18 May 2016, http://edition.cnn.com/2016/05/18/architecture/seananderson-moma-refugee-architecture/index.html. . See also Amale Andraos, "What Does Climate Change (for Architecture)?," in Climates: Architecture and the Planetary Imaginary, ed. James Graham (New York: Columbia University/Lars Müller, 2016), 297-301. "For architecture in particular, climate change is recasting the boundaries and interconnections that define the field-affirming that architecture is, in fact, a synthetic discipline," she contends. Ibid., 297.

2 These concerns have been acknowledged outside the realms of professional practice and higher education, as well. In 1995, a consortium representing U.S. elementary-level educators asserted that "An interdisciplinary education which draws from the knowledge and processes of multiple disciplines should encourage students to become active learners equipped with the analytical, interpretative, and evaluative skills needed to solve real-life problems." National Council of Teachers of English, "Position Statement on
} 
design and planning of cities (e.g., architecture, landscape architecture, and urban planning), such challenges have provoked the reassessment of long-standing professional identities and pedagogical models. The U.S. National Architectural Accrediting Board's inclusion among its explicit student learning aspirations, for example, that students be "broadly educated," cognizant of "people, place, and context" while "recognizing the disparate needs of client, community, and society," demonstrates the perceived value of broad-ranging approaches and transdisciplinary thinking as essential qualities of built environments education. ${ }^{3}$ Architecture, therefore, has explicitly acknowledged the need to learn and think beyond its own traditional disciplinary confines, as have the fields of landscape architecture and urban planning. ${ }^{4}$ At stake is the degree to which built environment specialists can effectively and collaboratively address the expanding needs and demands of those they serve, while cultivating a greater appreciation for the diverse and complex perspectives embodied by built environments. ${ }^{5}$ Educators in built environments

Interdisciplinary Learning, Pre-K to Grade 4," 14 August 2008, accessed 10 May 2016, http://www.ncte.org/positions/statements/interdisclearnprek4.

${ }^{3}$ National Architectural Accrediting Board, 2014 Conditions for Accreditation, 2014, accessed 10 May 2016, http://www.naab.org/f/documents/streamfile.aspx?sortfield=lastmodifiedlasc\&name=01_Final+Approved+ $2014+N A A B+C o n d i t i o n s+f o r+A c c r e d i t a t i o n . p d f \& p a t h=P u b l i c+D o c u m e n t s \% 5 C N A A B+N e w s \% 5 C$.

4 The U.S. Landscape Architecture Accreditation Board states that programs "shall provide an educational context enriched by other disciplines, including but not limited to liberal and fine arts, natural sciences, and social sciences, as well as opportunities for students to develop other areas of interest." See Landscape Architecture Accreditation Board, Accreditation Standards, 2016, accessed 10 May 2016, https://www.asla.org/uploadedFiles/CMS/Education/Accreditation/LAAB_ACCREDITATION_STANDARD S_March2016.pdf. The U.S. Planning Accreditation Board expects program graduates to have mastered the field of "general planning knowledge" with "appropriate perspectives from history, social science, and the design professions," see Planning Accreditation Board, Accreditation Standards and Criteria, 2012, accessed 10 May 2016, http://www.planningaccreditationboard.org/.

${ }^{5}$ Thus, the educational task here can be differentiated from other (more recently established) disciplines like urban studies that employ holistic, critical approaches to the study of built environments but operate beyond the structures of professional training and accreditation. Lest we be accused of 'academic amnesia', the notion that 'built environments' can be considered a meta-discipline, or comprised of several more-established disciplines, is not a new idea (with the Berlage Institute, which ran from 1990 to 2012 , being perhaps the most famous example). It also calls to mind the efforts in the 1950s to develop academic centers or 'area studies' to cluster disciplines that share common interests or practices, see Samuel S. Wineburg, Pamela L. Grossman, and Scott F. Beers, "Introduction: When Theory Meets Practice in the World of School," in Interdisciplinary Curriculum: Challenges to Implementation, eds. Samuel S. Wineburg and Pamela L. Grossman (New York: Teachers College, 2000), 5. 
programs are thus tasked with implementing curricular and pedagogical approaches that can better foster what might be called 'inter- or transdisciplinary empathy' in future professionals. ${ }^{6}$

This paper presents one example of pedagogical innovation: a new course offered by the University of Washington's (UW) College of Built Environments (CBE) intended to introduce the built environment to undergraduates who have not (yet) identified with any of the College's constituent fields (architecture, construction management, landscape architecture, urban design and planning), and may have limited awareness of the relevance and richness of such areas of knowledge.-Initially offered in the fall of 2015 to ninety students, "Introduction to Built Environments: Seattle on Foot" (Built Environments 200 or BE200) was designed and taught, with faculty supervision, by doctoral students in the College's PhD in the Built Environment (BE PhD) program. The course's curricular content, structure, and delivery methods reflected the instruction team's belief in the pedagogical value of place, the importance of foundational transdisciplinary skills and knowledge, and the cultivation of empathetic dispositions in future citizen-practitioners. The following essay first introduces the unique institutional context for the development of BE200, a significant factor in its design and implementation. It then outlines three pedagogical principles central to the course's conception-pre-disciplinarity, experiential, place-based learning, and instructional scaffolding—before describing BE200's content and successful implementation. Concluding remarks address the course's potential applicability as a model for built environments education in professional, liberal arts, and other contexts. Ultimately, BE200 represents a potentially effective course model for inspiring critical observation and thinking about cities as dynamic built environments, and for encouraging public engagement and lifelong learning.

\footnotetext{
${ }^{6}$ Complexities and limitations notwithstanding, the authors adopt the general perspective of Graff: "Careful, well-grounded and knowledgeable interdisciplinarity can be-but is not guaranteed to be-a valuable route to answering important questions and resolving or at least redefining problems, both new and old, large and small. It can propel teachers and researchers toward fundamental and more particular criticism and rethinking. It can lead to new approaches to old questions. It can promote conversations and collaboration...." Harvey Graff quoted in Scott Jaschik, "Undisciplining knowledge," Inside Higher Ed, 10 September 2015, accessed 11 May 2016, https://www.insidehighered.com/news/2015/09/10/authordiscusses-new-book-interdisciplinarity.
} 


\section{Institutional Context: The University of Washington's College of Built Environments}

Widespread enthusiasm for innovative, pre-disciplinary and non-traditional teaching and learning opportunities compels students, instructors, and researchers to pursue creative approaches that transcend existing disciplinary divisions, as it has at the University of Washington's College of Built Environments. Formerly the College of Architecture and Urban Planning, the unit adopted its more inclusive name in 2008 in order to better reflect the interdependence of the professional fields, while better encompassing the Departments of Construction Management and Landscape Architecture, both of which had been anonymously housed there since the 1960s. Ongoing work during the past decade to more fully realize this new identity has included the development of college-wide research centers, multi-departmental studios, and interdisciplinary-themed research interest groups designed to involve faculty and students from across the spectrum of allied built environments fields. Not unlike socially conscious 'environmental design' professionals of the 1960s and 1970s who fostered "a set of attitudes about how to arrange the physical elements in the environment to achieve a satisfying and rewarding human habitation," the CBE is committed to further engaging socio-cultural, ecological, and technical challenges confronting today's world. ${ }^{7}$ This approach is amply demonstrated by the work of over a dozen interdisciplinary centers and labs within the College.$^{8}$ Further incentivizing increased enrollment and more robust programs across the board, in 2013, the University of

\footnotetext{
${ }^{7}$ Richard P. Dober, Environmental Design (Huntington, NY: Robert E. Krieger, 1975), 175. Many of today's "built environment" programs stem from earlier experiments in "environmental design." For an earlier example of a college or faculty dedicated to the training of "environmental specialists," see S.D. Phillips and T.McL. Semple, "Environmental Dispositions and the Education of Environmental Specialists: A University Case Study," in New Directions in Environmental Design (vol. 2), ed. Walter Rogers and William Ittelson (Washington, D.C.: Environmental Design Research Association, 1978), 480-88. The University of Waterloo's Faculty of Environmental Studies at the time housed its School of Architecture, School of Urban and Regional Planning, Department of Geography, and Department of ManEnvironmental Studies.

8 University of Washington College of Built Environments, "Labs + Centers," accessed 9 May 2016, http://www.be.washington.edu/research/labs-and-centers/.
} 
Washington transitioned to an activity-based budgeting (ABB) system, wherein funds are allocated based on tuition revenues derived from unit courses. ${ }^{9}$

The UW BE PhD program, established in 2003 and housed within the office of the CBE Dean (rather than a department), is a unique manifestation of larger trends in non-traditional institutional systems and scholarship in the built environments. Functioning as a sort of interdisciplinary 'fifth space' within the College, it draws from and complements the work of the College's four constituent departments. ${ }^{10} \mathrm{BE}$ PhD students, who come from diverse backgrounds including design, history and theory, engineering, and public health, are trained to work collaboratively as researchers and practitioners towards the amelioration of significant socioenvironmental problems. ${ }^{11}$ Due to its college-wide nature, its explicit interdisciplinary aims, and the diversity of its students' perspectives, the BE PhD program is in an excellent position to develop and staff new, non-traditional course offerings. Such endeavors have the added benefits of providing much-needed funding and professional/teaching development opportunities consistent with the program's mission, ${ }^{12}$ while facilitating the expansion of enrollment at the College. Indicative of widespread acknowledgement of this optimal positioning, BE200 was the product of a supportive coalition of volunteer BE PhD students, program faculty and steering committee members, and the College's department chairs and Dean.

\footnotetext{
9 University of Washington Office of Planning and Budgeting, "Activity Based Budgeting," accessed 22 April 2016, http://opb.washington.edu/activity-based-budgeting.

10 Such a characterization recognizes the less formalized intellectual community-making aspect of the program, drawing on the "third place" concept popularized by Oldenberg in 1989. See Ray Oldenberg, The Great Good Place (Cambridge, MA: Da Capo, 1999).

11 Students pursue one of the program's three broadly defined and inherently interdisciplinary specializations including Sustainable Systems and Prototypes, Technology and Project Design/Delivery, and History, Theory, and Representation. See University of Washington College of Built Environments, "BE PhD," accessed 22 April 2016, http://be.washington.edu/phd/.

12 On the importance of professional (specifically teaching) development for doctoral students, see Chris Golde, "Teaching Development for All Doctoral Students: It's Time," Grad Logic, 19 April 2016, accessed 20 June 2016, http://gradlogic.org/lsfss/.
} 
Acknowledging that larger institutional concerns inspire and shape curricular and pedagogical developments, ${ }^{13}$ BE200 was designed to challenge existing curricular pathways while opening students' avenues for less restricted engagement and growth. The CBE's departmental structure and typical coursework patterns generally reinforce longstanding divisions between built environments professions, and professional accreditation standards frequently limit curricular innovation. ${ }^{14}$ Indeed, nearly all CBE courses are taught through separate departments; and though occasionally cross-listed and team-taught in an effort to expand content, they typically fit within the professional and methodological parameters established by their respective fields. Undergraduate students typically enroll in pre-major courses offered by particular departments (or are required to do so for entry), but there are few opportunities to explore built environments in a truly inter- or transdisciplinary fashion. ${ }^{15}$ Students therefore contribute, whether they realize it or not, to the reproduction of disciplinary silos as soon as they begin their studies in the College. The conception of BE200 is an attempt to address the lack of transdisciplinary opportunities by offering course content that is representative of the College's programs without explicitly yielding to disciplinary pipelines (Figure 1).

${ }^{13}$ David Kolb, Experiential Learning: Experience as the Source of Learning and Development (Upper Saddle River, NJ: Pearson, 2015), 284-87.

${ }^{14}$ Accreditation requirements are often cited as limiting factors that prevent more exploratory coursework in professional design schools, despite the fact that (as noted above) disciplines are increasingly obliged to engage in interdisciplinarity by these standards.

15 The recent expansion of joint-degree programs, such as those between architecture and landscape architecture, reflects increased student interest in more holistic approaches to curriculum design at the College level. 


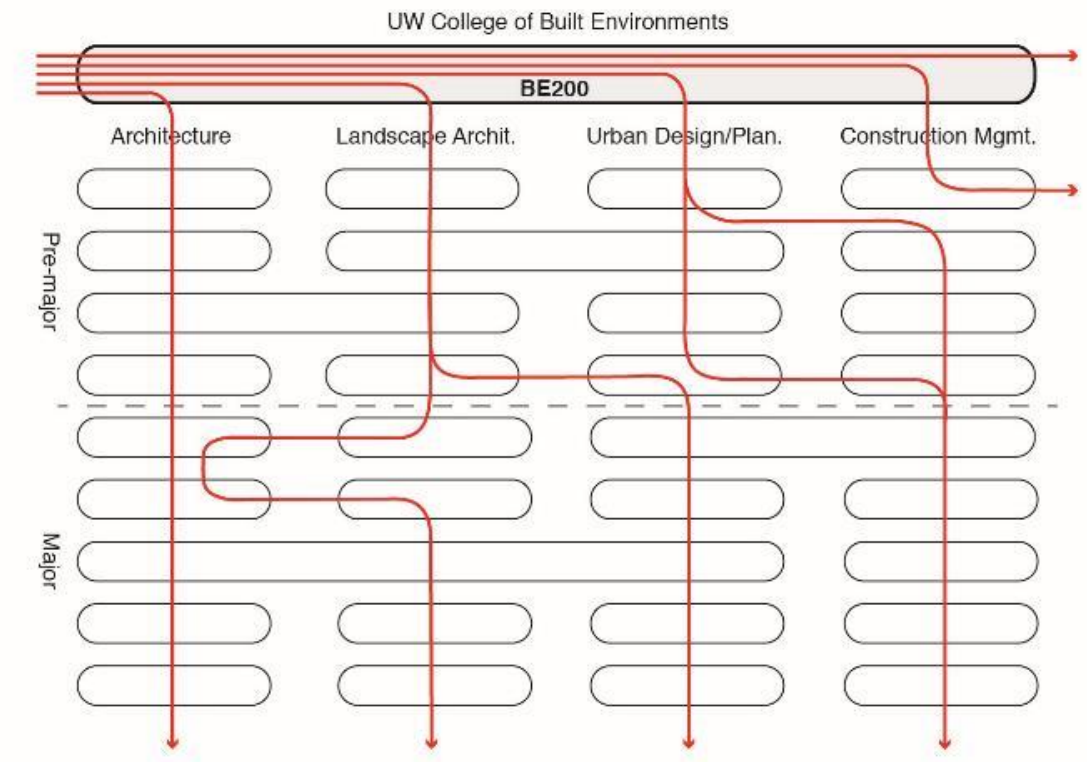

Figure 1. UW CBE institutional context and hypothetical student pathways through the College's course offerings. BE200 functions as an optional pre-disciplinary gateway course within a generally 'siloed' college organization.

Source: authors

Free from professional accreditation constraints because most CBE undergraduate programs are non-accredited, this course functions as an ideal gateway elective most suited for underclassmen interested in exploring —rather than (perhaps prematurely) committing to—built environments and potential career paths.

\section{BE200 Pedagogical Principles}

Three primary pedagogical principles emerged from more than six months of exploratory conversations and collaborative preparation: the touchstone concept of pre-disciplinarity, the centrality of experiential, place-based learning, and the use of instructional scaffolding that include traditional lectures and small group discussion sessions with immersive explorations of course content through curated city walks. Contemporary Seattle's dynamic nature greatly inspired the methods and content of BE200, as well, and the city's built environment functioned as a major pedagogical component of the class' implementation. The resulting course was designed to facilitate what Fink calls "significant learning" experiences, wherein students develop knowledge 
of foundational information, practice critical thinking and connect ideas, cultivate compassion for the human dimension, and develop better learning practices. ${ }^{16}$

\section{Pre-disciplinarity}

Rigorous debate regarding the arguably stagnant state of higher education has produced an array of proposed solutions in the past decade, ${ }^{17}$ and interdisciplinarity figures prominently in many. ${ }^{18}$ Some have argued for the focused augmentation of specific interdisciplinary aspects of existing interdisciplinary fields, resisting what they see as the 'false panacea' of interdisciplinarity. ${ }^{19}$ Others champion the abolition of traditional disciplines and university departments in order to facilitate unrestricted "cross-disciplinary and cross-cultural" scholarship. ${ }^{20}$ Indeed, numerous terms have emerged that express this range of approaches to education and practice-including the most familiar ones like 'interdisciplinary,' 'transdisciplinary,' and 'multidisciplinary,' as well as more radical ones like 'post-disciplinary' and 'anti-disciplinary.'

Rather than introducing the built environment as the sum of disciplinary knowledges through the presentation of each separate discipline in succession, as is often done, a "predisciplinary' approach to built environments education privileges shared topics and perspectives over professional distinctions. Like a successful interdisciplinary course, a 'pre-disciplinary' course supports the broader aim of fostering open-minded thinking among students who might someday be required to adapt in uncertain and unknowable futures, without undermining the

\footnotetext{
${ }^{16}$ L. Dee Fink, Creating Significant Learning Experiences (San Francisco: Jossey-Bass, 2013), 34-37.

17 On the state of higher education and attempts by some to effect change see Richard DeMillo, Revolution in Higher Education (Cambridge, MA: MIT, 2015).

${ }^{18}$ For a brief history of the notion of interdisciplinarity, see Harvey J. Graff, Undisciplining Knowledge: Interdisciplinarity in the Twentieth Century (Baltimore, MD: Johns Hopkins University, 2015), 1-19. 19 Jerry Jacobs, "Interdisciplinary Hype," Chronicle of Higher Education, 22 November 2009, accessed 10 May 2016, http://chronicle.com/article/Interdisciplinary-Hype/49191/.

20 Mark Taylor, "End the University as We Know it," New York Times, 26 April 2009, accessed 10 May, 2016, http://www.nytimes.com/2009/04/27/opinion/27taylor.html. Among many innovate graduate programs established in recent decades, Stanford's design school, for example, has positioned itself as a critical "anti-university" in its explicitly "context-dependent" approach to interdisciplinary learning. Peter Miller, “Is 'Design Thinking' the New Liberal Arts?" Chronicle of Higher Education, 26 March 2015, accessed 2 June 2016, http://chronicle.com/article/ls-Design-Thinking-the-New/228779/.
} 
importance of specific disciplines and specialist professions. ${ }^{21}$ Ultimately, the aim of such an approach is the development of graduates capable of collaborating across disciplines and with members of the non-specialist community, and who appreciate the planet's complexity and the coexistence of multiple worldviews. The prefix 'pre-' therefore connotes the significance of instilling this wider appreciation at an introductory level, occurring in the curriculum chronologically before disciplinary training but without seeking to undermine the value of disciplinary knowledge. Thus, a pre-disciplinary approach to the built environments would attend to predominant disciplinary ways of knowing, both shared and divergent, as well as the values and perspectives of constituents locally served, while refraining from essentializing disciplinary identities through false distinctions. It furthermore allows students who may yet be unsure of their interests, or potential fields of knowledge and career paths, to tentatively investigate without major commitment or risk.

A pre-disciplinary approach is both interdisciplinary (in that it assembles and synthesizes disciplinary knowledges) and transdisciplinary (in that it seeks to foster ways of knowing that transcend disciplinary methods). Thus, such an approach can accomplish two primary goals: it can establish the foundation for more effective public engagement and collaboration among disciplines by introducing ways of knowing that can instill 'inter- or transdisciplinary empathy, ${ }^{22}$

\footnotetext{
${ }^{21}$ In this case, 'pre-disciplinary' does not refer to various attempts in K-12 contexts to focus on "commonsense themes that draw little on disciplinary ways of knowing." See Wineburg and Grossman, Interdisciplinary, 4, referencing Howard Gardner and Veronica Boix Mansilla, "Teaching for Understanding in the Disciplines and Beyond," Teachers College Record 96 no. 2 (1994): 198-218. 22 See a similar appeal for empathy in engineering education by Joachim Walther, Shari E. Miller, and Nadi N. Kellam, "Exploring the Role of Empathy in Engineering Communication Through a Transdisciplinary Dialogue" (paper presented at the American Society for Engineering Education Annual Conference, San Antonio, Texas, June 10-13, 2012), accessed 10 May 2016, https://www.asee.org/public/conferences/8/papers/4670/view. The idea that citizens ought to be more involved (and actively welcomed by professionals) in built environment decision-making is of course not new. In 1978, for example, Michael Sweeney contended that "The role of the professional planner and designer must be redirected towards increasing the design awareness of the people who must live with the planning and design decisions affecting the built environment." See Michael Sweeney, "Who Designs the Built Environment? A Model for Public Awareness in Environmental Design," in New Directions in Environmental Design (vol. 2), ed. Walter Rogers and William Ittelson (Washington, D.C.: Environmental Design Research Association, 1978), 499.
} 
and it can illuminate disciplinary 'blind spots' by shedding light on issues that fall between or beyond the traditional epistemological purview of disciplinary matrices. Empathy entails respecting differences in worldview as meaningful contributions to decision-making among future design practitioners (and citizens at large). Indeed, the multicultural nature of cities and the need for more pluralistic approaches to their planning and design necessitates the type of cultural literacy cultivated by such empathetic perspectives. ${ }^{23}$ Blind spots would include issues traditionally overlooked by the collective fields and professions associated with the built environments. For example, concepts like spatial justice or informal urbanism, the concern of fields like urban studies and geography for several decades, have only recently received attention within the academy's built environment programs. The further exposure of blind spots in academia could effectively mitigate some of the not uncommon disconnect between the concerns of professionals and students, thereby enhancing the relevance of both education and practice.

\section{Experiential and Place-Based Learning}

Direct experience with one's surroundings, presumably the preeminent mode of premodern education, ${ }^{24}$ offers much to contemporary teaching and learning because "The vitality of human settlements cannot be adequately experienced second-hand" or abstractly. ${ }^{25}$ While substantial developments in technology-based pedagogies have been made in recent decades, and digital media continue to expand opportunities for learning beyond the confines of the traditional classroom, the intentionally 'analog' approach adopted by the BE200 team successfully immersed students, as active agents, in the subject of their study. ${ }^{26}$ As Joplin writes in her

\footnotetext{
${ }^{23}$ Leonie Sandercock, Towards Cosmopolis: Planning for Multicultural Cities (New York: Wiley, 1998)

${ }^{24}$ Daniel U. Levine, "Experiencing the City," Journal of Experiential Education 1 no. 2 (1978): 13-19. For more on the theory of experiential learning, see Kolb, Experiential.

${ }^{25}$ Levine, "Experiencing the City," 19.

${ }^{26}$ For examples of recent innovations in integrating technology in the classroom see Anon., "The Digital Campus: Tech Innovators 2016," Chronicle of Higher Education, accessed 10 May 2016, http://chronicle.com/specialreport/The-Digital-Campus-Tech/35, and at the UW, Gerald J. Baldasty and Marisa Nickle, eds., "Innovators Among Us: When Technology Brings Learning to Life," accessed 10 April 2016, http://www.washington.edu/trends/innovators-among-us-when-technology-brings-learning-to-life/. Debate regarding the utility and efficacy of in-class technology continues. See, for example, Kentaro
} 
explication of experiential education, "Direct experience provides the substance from which learners develop personal meaning." ${ }^{27}$ By connecting to places viscerally and sensorially, learning is less mediated and more complicated-both factors that are important for appreciating the built environment as a subject. Importantly, experiential and place-based education can also be antidotes to some of the drawbacks of classroom-based learning, wherein students are separated from real world environments and life situations. ${ }^{28}$ As Smith argues, "The primary value of placebased education lies in the way that it serves to strengthen...[students'] connections to others and to the regions in which they live." 29 It can furthermore improve achievement, but more importantly, he continues, place-based education "helps [students] overcome the alienation and isolation of individuals that have become hallmarks of modernity." 30

Those engaged in place-based learning processes benefit personally from their experiences largely because spaces themselves can act as teaching tools, a point made succinctly by Gruenewald when he says that

places are profoundly pedagogical. That is, as centers of experiences, places teach us about how the world works and how our lives fit into the spaces we occupy. Further, places make us: As occupants of particular places with particular attributes, our identity and our possibilities are shaped. ${ }^{31}$

Not only are spontaneously experienced places inherently didactic, but through mediation by instructors their educational potential is harnessed and focused towards specific instructional goals. Foregrounding experiential learning, particularly in introductory courses, demystifies complexity. It allows students to reflect upon and critically challenge their pre-existing

Toyama, "Why Technology Will Never Fix Education," Chronicle of Higher Education, 19 May 2015, accessed 10 May 2016, http://chronicle.com/article/Why-Technology-Will-Never-Fix/230185/.

${ }^{27}$ Laura Joplin, "On Defining Experiential Education," Journal of Experiential Education, 4 no. 1 (1981): 20. Joplin categorizes all learning as fundamentally experiential but recognizes a difference between learning and education (which at its best is experiential).

28 Gregory A. Smith, "Place-based Education: Learning To Be Where We Are," Phi Delta Kappan 83 (2003): 594.

29 lbid.

$30 \mathrm{lbid}$.

31 David A. Gruenewald, "Foundations of Place: A Multi-disciplinary Framework for Place-conscious Education," American Educational Research Journal 40 no. 3 (2003): 621. 
interpretations of the built environment, as well as their emerging perspectives on intellectual ideas. It allows them to experience urban spaces and moments with which they are likely already familiar through an increasingly informed and transformed perspective. Employing the surrounding urban environment as a pedagogical space offers students and instructors a shared point of reference, in effect democratizing access to course material. But, more importantly, it provides an opportunity for students to recognize through discussion that others can interpret the same point of reference in a multitude of meaningful ways. That is, students are presented with (and hopefully come to appreciate) the inherently multivalent built environment through the richness of multisensorial experience, as well as the diversity of perspectives represented in their learning community.

Emerging from the human experience as is an inherently open-ended and personal method, experiential learning is a fruitful pre-disciplinary pedagogical mode. Through curated walks, students can come to appreciate the state of the built environment, as well as the particular manifestations of the course themes. The concept of walking as an informative experience has a long history, particularly within the modern urban context. Charles Baudelaire, for example, championed the "gentleman stroller of city streets" and the "botanist of the sidewalk" in a rapidly modernizing Paris, cultivating the character of the nineteenth-century's ambling urbanite or flaneûr. ${ }^{32}$ A century later, Kevin Lynch inspired environmental designers and planners through his seminal work on urban "imageability," The Image of the City, and made clear the significance of walking as a means of transportation and method for visualizing and knowing the city's form. ${ }^{33}$ Writing further on everyday spatial practices, Michel de Certeau famously ascribed to walking the ability to make spaces when he asserted that "space is a practiced place...transformed by walkers" who give the city meaning. ${ }^{34}$ Drawing on this phenomenological conceptualization,

\footnotetext{
32 Charles Baudelaire, "The Painter of Modern Life," Le Figaro, 1863.

${ }^{33}$ Kevin Lynch, The Image of the City (Cambridge: MIT, 1960); Dober, Environmental Design, 178-79.

${ }^{34}$ Michel de Certeau, The Practice of Everyday Life, trans. Steven Rendall (Berkeley: University of California, 1984): 117.
} 
Wunderlich presents walking as "an embodied practice with specific lived qualities," but also a critical "mode of experiencing place and the city," and thus "an aesthetic and insightful spatial practice." 35 She identifies three primary modes of walking, categorizing the activity as "purposive," "discursive," and "conceptual." 36 The first mode includes walking as intentional and explicit transportation, while the second is aimless wandering in the style of the flaneûr or a Situationists' spontaneous dérive. "Conceptual walking," however, involves the thoughtful exploration and engagement with space and as such describes the type of focused critical experience of place endorsed by BE200. A "reflective mode," conceptual walking is therefore a "creative response to our interpretation of place," or more simply "a way of gathering information, or critically building awareness of urban environments." ${ }^{37}$ Walking, conceived in this way, provides significant opportunities to engage dynamic built environments through multiple senses and with a critical awareness fundamental to BE200.

Walking to learn is a particularly compelling method within the larger context of an incredibly dynamic Seattle in which the interconnected nature of constructed environments and related socio-cultural issues is abundantly apparent. Experiencing technology industry-inspired population growth at levels on par with the Klondike Gold Rush, the city is now undergoing considerable demographic shifts and restructuring. ${ }^{38}$ Rent increases are among the nation's

\footnotetext{
${ }^{35}$ Filipa Wunderlich, "Walking and Rhythmicity: Sensing Urban Space," Journal of Urban Design 13 no. 1 (2008): 125. Some scholars, such as Middleton, have addressed the divide between common, policybased considerations of walking that stress its health and sustainability benefits as transportation, and theoretical abstractions of academics that "lack any systematic empirical exploration of actual pedestrian practices." See Jennie Middleton, "Sense and the City: Exploring the Embodied Geographies of Urban Walking," Social \& Cultural Geography 11 no. 6 (2010): 575.

${ }^{36}$ Wunderlich, "Walking," 131-33.

37 Ibid., 132. Jacks' conceptualization of "merging" through walking—-"plunging into the immediate environment" with a "heightened sense of awareness of time and consciousness"-relates to Wunderlich's "conceptual walking," opening opportunities for more embodied practices of creative walking that extend beyond the BE200 pedagogical framework, and therefore demonstrating the theoretical potential of walking as a creative act. See Ben Jacks, "Reimagining Walking: Four Practices," Journal of Architectural Education 57 no. 3 (2004): 8.

38 Gene Balk, "Seattle's Population Boom Approaching Gold Rush Numbers," Seattle Times, 13 September 2015, accessed 10 May 2016, http://www.seattletimes.com/seattle-news/data/seattlespopulation-boom-approaching-gold-rush-numbers/. From 2012-2013 Seattle was the fastest growing city in the U.S. $(+2.8 \%)$. The following year it placed third with $2.3 \%$ growth. See Gene Balk, "Seattle No
} 
highest, and gentrification challenges longstanding neighborhood identities, while issues related to public space access, the preservation of green space and historic landmarks, architectural authenticity, homelessness and drug use, overtaxed transportation systems, and insufficient urban infrastructure command considerable attention in city hall, in headlines, and in the street (Figure 2). ${ }^{39}$

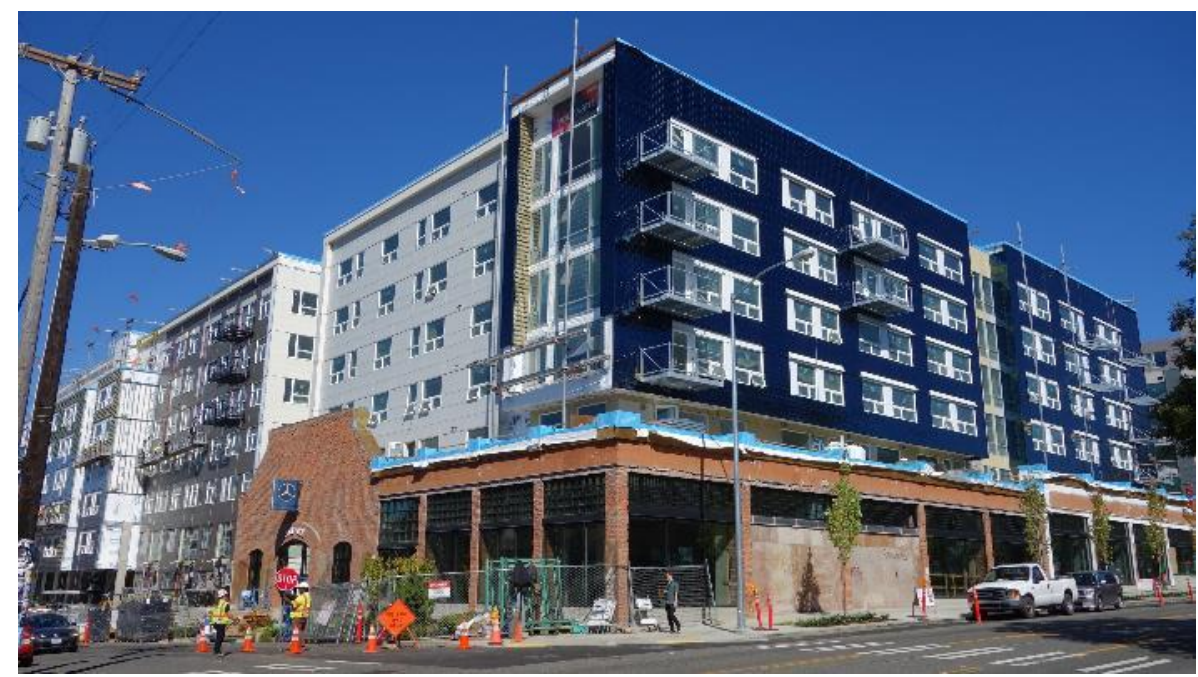

Figure 2. Façadism in the Capitol Hill neighborhood, Seattle (2015). Only part of the former car dealership's exterior shell survives beneath the massive new apartment block. Projects like this are now common in the area, challenging prevailing notions of architectural authenticity and historic preservation within the city's former "auto-row" streetscape. Source: Daniel E. Coslett

New towers reach unprecedented heights as districts are rezoned to accommodate growth, while at the same time, demolition permits are being filed at a rate nearly six times that of $2010 .{ }^{40}$ Busy developers and vocal politicians champion the merits of increased density, while frustrated community advocates argue for better funding and more equitable distribution of bus routes. The

Longer America's Fastest-growing Big City," Seattle Times, 21 May 2015, accessed 10 May 2016, http://www.seattletimes.com/seattle-news/data/seattle-no-longer-americas-fastest-growing-big-city/. 39 For example, on gentrification in Seattle's LGBTQ-friendly Capitol Hill neighborhood, see Tricia Romano, "Cultures Clash as Gentrification Engulfs Capitol Hill," Seattle Times, 13 March 2015, accessed 22 April 2016, http://www.seattletimes.com/life/lifestyle/culture-clash-on-capitol-hill/. Seattle's gross median rent jumped nearly $11 \%$ between 2010 and 2013, the highest in the US's 50 largest cities during that time. See Gene Balk, "Census Data: Seattle Saw Steepest Rent Hike Among Major U.S. Cities," Seattle Times, 18 September 2014, accessed 10 May 2016, http://www.seattletimes.com/seattlenews/data/census-seattle-saw-steepest-rent-hike-among-major-u-s-cities/.

40 Schema Design, "Changing Seattle: Tracking Demolition Permits," Arcade 33 no. 2, 13 October 2015, accessed 10 May 2016, http://arcadenw.org/article/changing-seattle. 
conversations and publicity generated by such change, tumultuous for many, has seeded fertile ground for the study of contemporary built environments and the complex processes linked to their generation and development. The complexity and urgency of such immediately relevant, built environment-related issues underscores the need for novel approaches to educating those involved in designing, planning, managing, and interpreting the city. While engaging the constructed environment directly through walking functioned as the most central learning mode, the broader learning goals of the course were pursued through the use of a variety of scaffolded activities and delivery modes.

\section{Instructional Scaffolding}

Undergraduate-level, pre-major, elective courses arguably tend to attract a wide range of learner types, including those with preferences for auditory, visual, reading/writing, and kinesthetic modes of learning, as well as those from diverse linguistic, cultural, and academic backgrounds. For a course with pre-disciplinary motives, exploring knowledge and facilitating engagement with the built environment using methods meaningful to a diversity of learning types is particularly appropriate. ${ }^{41}$ Pedagogically, the diverse ways of knowing and being embodied within the built environment and its related professions warrant the inclusion of multiple activity and participation structures, or a variety of ways that students can engage with course material-socially, cognitively, and physically. ${ }^{42}$ Furthermore, the complex composition of the city warrants the use of what one might label a 'mixed qualitative methods' approach to teaching, just as it often applies to effectively researching built environments. Thus, any attempt to introduce the built

\footnotetext{
${ }^{41}$ Gardner's theory of "multiple intelligences" suggests that courses employing a broad array of frameworks and methodologies will enhance student engagement, and thus learning. See Howard Gardner, Frames of Mind: The Theory of Multiple Intelligences (New York: Basic, 1983). For further discussion of his much-debated ideas, see Todd Finley, "Are Learning Styles Real-and Useful?" Edutopia, 22 September 2015, accessed 31 May 2016, http://www.edutopia.org/article/learning-stylesreal-and-useful-todd-finley.

42 For a summary of recent research on classroom participation structures (and their relationship to lowerachieving students in this case), see Sean Kelly and Julianne Turner, "Rethinking the Effects of Classroom Activity Structure on the Engagement of Low-achieving Students," Teachers College Record 111 no. 7 (2009): 1665-92.
} 
environments in its broadest conceptual sense_as an object, subject, and pedagogical settingwould be improved through the deployment of multiple activity structures, while considering how the theories of learning underlying these structures might have a complementary rather than a contradictory effect on student development. To these ends, BE200 creators adopted an instructional scaffolding approach, organizing the course around an integrated set of delivery modes and activities.

More traditional forms of content delivery, such as 'live,' instructor-delivered lectures, remain effective for stimulating higher-order thinking in an age of flipped and hybrid classrooms. ${ }^{43}$ In courses adopting an experiential approach to learning, such modes of delivery that are not immersive (like readings and presentations) may function as valuable prologues to more active modes of engagement, such as experiential, dialogical, and reflective activities. Indeed, Joplin, in her helpful synthesis of successful experiential learning processes, refers to this as a "focus" phase during which learners prepare for the forthcoming immersive or experiential "challenging action." ${ }^{44}$ During this first stage, facilitators "present...the task and isolate...the attention of the learner for concentration" through conversations, presentations, readings, etc. before learners embark on immersive physical, mental, emotional, or spiritual activities, making use of unmediated "original sources." ${ }^{45}$ To be most successful, Joplin continues, this primary action ought to be followed by a reflective "debrief" phase-an oft-overlooked but integral component of experiential learning and creative design thinking. ${ }^{46}$ As "Experience alone is insufficient to be called experiential education...," participants must participate in a 'public' reflexive process of "sorting and ordering...information" through which "learning is recognized, articulated, and

${ }^{43}$ Catherine Matheson, "The Educational Value and Effectiveness of Lectures," The Clinical Teacher 5 (2008): 218-21.

44 Joplin, "Experiential," 18.

45 lbid.

46 Yi-Chun Hong and Ikseon Choi, "Three Dimensions of Reflective Thinking in Solving Design Problems:

A Conceptual Model," Educational Technology Research and Development 59 (2011): 687-710. 
evaluated." 47 Repeated within a larger context of instructional support and feedback, this actionreflection cycle of instructional scaffolding allows knowledge and experiences to accumulate. Each iteration thereby informs and enriches subsequent learning moments. The intent of such a scaffold is to support students as they move from pre-course conceptions, to initial (re)exposure and active engagement through the class, to the cultivation of a personal critical perspective.

Ultimately, a pre-disciplinary and immersive course using mixed qualitative methods can facilitate what Fink calls "significant learning" experiences, wherein students develop knowledge of foundational information, practice critical thinking and connect ideas, cultivate compassion for the human dimension, and develop better learning practices. ${ }^{48}$ This type of integrated competence, difficult to achieve through institutional course distribution requirements, can be effectively accomplished through the development of pre-disciplinary and experiential gateway introductory courses such as BE200. ${ }^{49}$ Carefully designing the course to maximize engagement and pedagogical diversity has proven effective for the entire BE200 community of learners (including both students and instructors), and what follows is an account of its structure and content, which may serve as a model or inspiration for others with similar objectives.

\section{BE200 Course Design and Structure}

BE200 was designed to specifically address the various needs of the University, College, BE PhD program, faculty, and students, and to engage the city of today in an insightful and compelling fashion. In developing the class structure and content, the course development and instruction team (comprised of three advanced BE PhD students and a faculty advisor) maintained the aforementioned core principles_-pre-disciplinarity, experiential and place-based learning, and instructional scaffolding. Course objectives included introducing students to the array of culturally

\footnotetext{
47 Joplin, "Experiential," 17 and 19.

${ }^{48}$ Fink, Creating, 34-37.

49 Kolb, Experiential, 285.
} 
significant and enmeshed issues related to contemporary built environments, supporting students' personal development in terms of interpreting and articulating built environment-related themes, and introducing students to Seattle as a physical and dynamic manifestation of these themes with lived consequences. The CBE's desire to see increased enrollment in college courses and programs and the cultivation of a broader appreciation of built environments fields amongst the general public was also considered. Finally, for students enrolled in the course-most of whom came directly from high school, and many of whom hailed from overseas - the class provided an opportunity to better know Seattle and to explore built environments issues at an accessible, introductory level.

\section{Course Content and Themes}

Impressed and inspired by the dynamic nature of Seattle today, and mindful of its potential as a thoroughly engaging learning environment, the course instruction team identified a series of thematic lenses through which one might approach built environments in general. Critical issues broadly relevant and easily engaged in Seattle-including natural and urban cultural landscapes, public space and access, transportation and equity, the past and preservation, globalization and urban identity-were captured by Green City, Public City, Mobile City, Historic City, and Global City course themes. These topics relate to the disciplines of architecture, urban planning, landscape architecture, and construction management in different fashions and at different scales, overlapping and linking up in meaningful ways that highlight the truly trans- and interdisciplinary nature of the city's form and function, making them particularly appropriate. For example, historic preservation concerns influence decision-making regarding transit infrastructure and rebuilding for increased densities in a globalizing city, while proposed transportation projects also inherently engage issues of economic development, environmental sustainability, and equity in public service provision. Clearly applicable to Seattle and beyond, these themes also engage many of the research interests of CBE faculty and doctoral students, a decision strategically made to see the course reflect and respond to the College's ongoing scholarly activity. Though far from 
an exhaustive set, this group of interrelated themes functions as a strong and expandable core for BE200. ${ }^{50}$

\section{Course Structure and Process}

BE200 featured five modules corresponding to its five primary themes. Each module, a complete action-reflection cycle, was structured around a curated, theme-based walk, each of which was framed by both in-class and out-of-class activities (Figure 3).

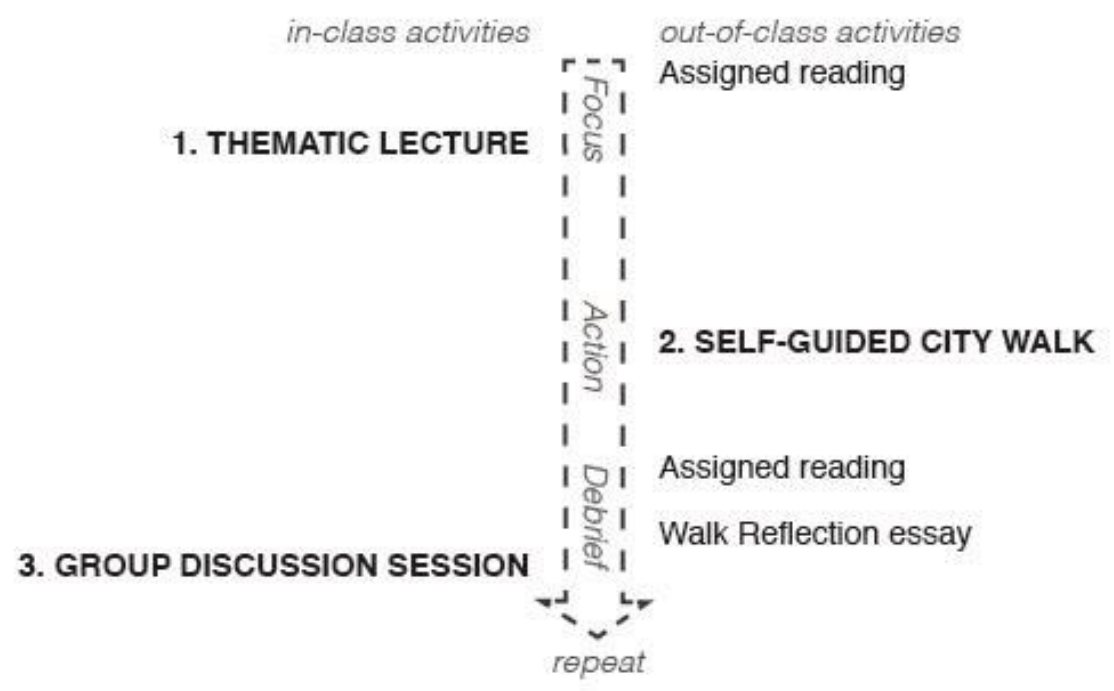

Figure 3. BE200 tripartite module format and workflow. The course's instructional scaffolding incorporates in-class and out-of-class activities through focus, action, and reflection stages (see Joplin, "Experiential”) to improve 'significant learning.' BE200 consists of five of these modules, each with a different theme.

Source: authors

The modules each included a full lecture, a walk, and a smaller group discussion session, as well as a short writing assignments based on assigned readings and in response to individuals' experiences during the walks. The implementation of the modules followed the experiential learning focus-action-debrief phasing suggested by Joplin. The course also included introductory and concluding lectures (the former on the Changing City and the latter on the Future City), as

\footnotetext{
${ }^{50}$ Additional themes considered included Healthy City (with a focus on public health), Informal City (with a focus on transience and public services), and Spectacular City (with a focus on urban spectacle and entertainment). Though these were unexecuted due to time constraints and the teaching team's areas of expertise, they would likely work well in the future or in expanded iterations of the course.
} 
well as a final session designed to introduce students to the College's four departments and their programs. This last class underscored the ways in which the disciplines might address the issues explored in the course, and functioned as a potential segue into the disciplinary CBE coursework students might undertake after completing BE200. ${ }^{51}$

As stated above, each thematic course module-Green City, Public City, Mobile City, Historic City, Global City—consisted of three parts, including a lecture, an independently conducted walk completed at students' convenience, and a follow-up discussion session, with out-of-class reading and writing assignments interspersed. Lectures focused on the module's specific theme and drew in part upon readings assigned to students for that module. Texts at this stage were chosen to introduce basic concepts in language appropriate for target students' learning levels and to compellingly preface the theme-based walk, while at the same time highlighting specific, critical stances. For example, readings (and lectures) articulated causes including ecological conservation, protest and activism, and reduced discrimination in planning. Wherever possible, theoretical pieces were supplemented with complementary, Seattle-based case studies. For example, within the Public City module, students read from Jeff Hou's Insurgent Public Space about the regulation of the public realm, as well as Witold Rybczynski's architectural review of Seattle's City Hall and Central Library (both of which students would visit during their walks). ${ }^{52}$ This pairing was done to lay the groundwork for making connections between theoretical ideas and their built manifestations in the city, both in the classroom and on the street. Given the pre-disciplinary and introductory nature of the course, reading content often emerged from

\footnotetext{
51 Ultimately demonstrating the relevance of the BE200 approach, the presentations made by department representatives conveyed significant (transdisciplinary) overlap in terms of contemporary concerns and methodological approaches, with each discipline considering 'the city' in its totality to fall within their purview. The session was also helpful for clearing up misconceptions about the professions, such as the true nature of landscape architecture (i.e. that it is more than just planting ornamental flora).

52 Jeff Hou, Insurgent Public Space: Guerilla Urbanism and the Remaking of Contemporary Cities (New York: Routledge, 2010) and Witold Rybczynski, "Revisiting Rem Koolhaas's Central Library and Peter Bohlin's City Hall in Seattle," Architect, April 2013, accessed 27 April 2016, http://www.architectmagazine.com/design/revisiting-rem-koolhaass-centrallibraryand-peter-bohlins-city-hall-in-seattle_o.
} 
humanities, literary, or popular media perspectives, rather than publications intended for professional or bureaucratic audiences.

As walking is an acknowledged form of embodied information-collecting with great potential for individual learning and interpretation, the course's thematic walks were its hallmark features. More than simply self-guided walking tours through different Seattle neighborhoods, the specific routes were chosen in order to reinforce each module's theme, expose participants to a variety of built morphologies and neighborhoods, and provide diverse opportunities for individual exploration and critical thinking (Figure 4).

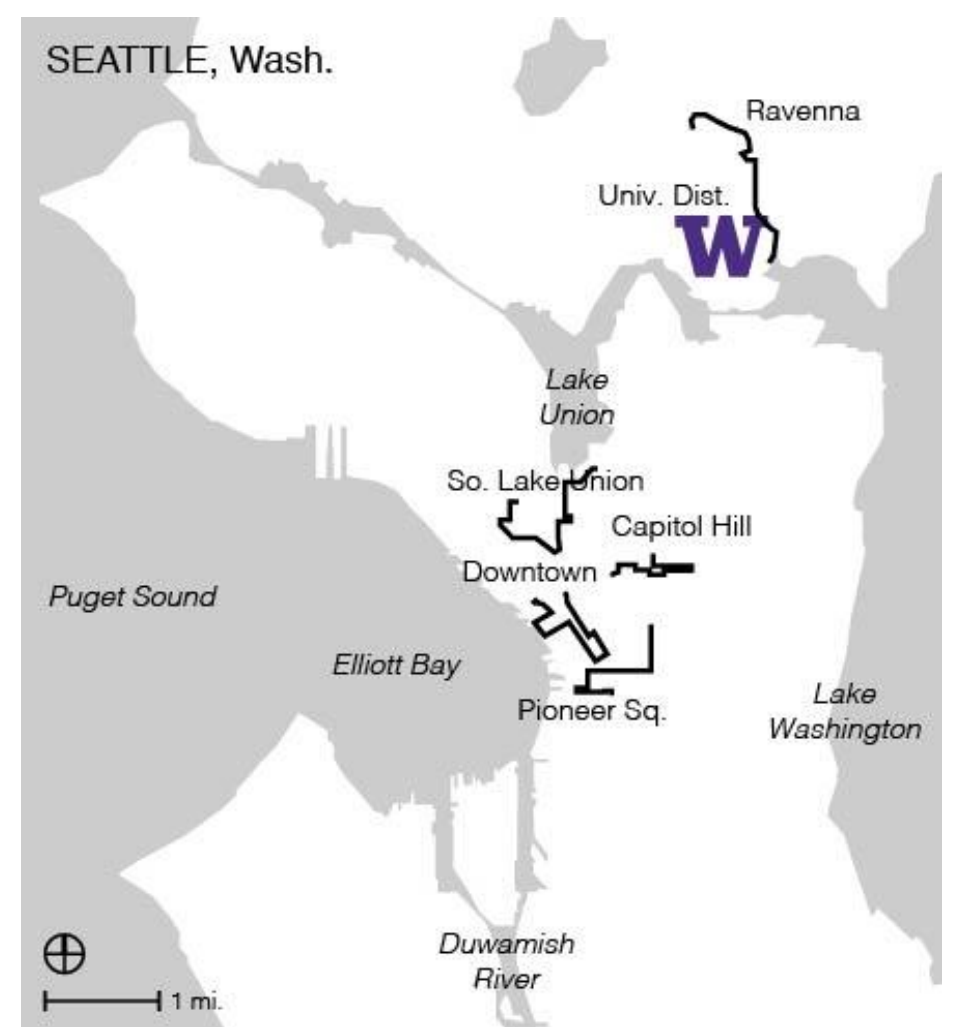

Figure 4. BE200 walk routes through Seattle (2015). Five walks were strategically paired with neighborhoods deemed most appropriate for each theme's exploration. All routes were accessible via public transportation from campus (marked with 'W') and intended to be completed in about ninety minutes.

Source: authors

Ranging from 1.65 to 2.3 miles in length, the walks were designed to be completed in ninety minutes, or the length of the class period. Their duration depended on students' speed and level of engagement, however, because at times participants were invited to deviate from planned 
itineraries and to explore accessible interior spaces in potentially meaningful moments of independent discovery and contemplation. Logistical information, routes, and points of interest were included in walk guides designed by instructors and distributed to students in hard copy (Figure 5).
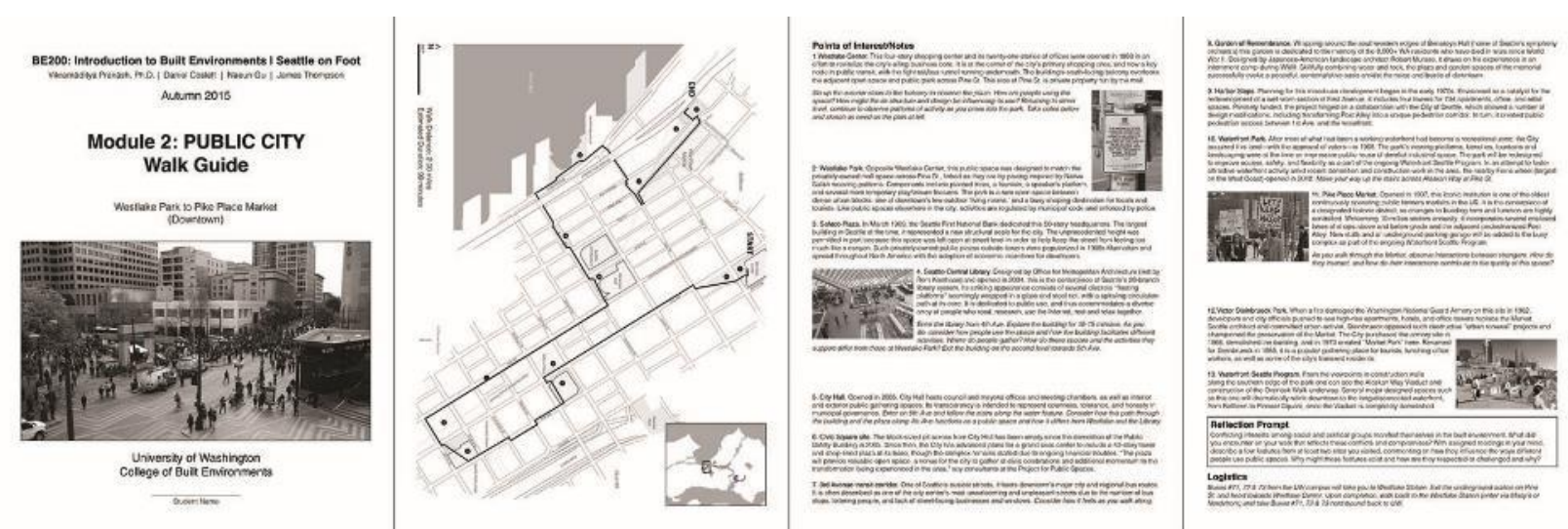

Figure 5. BE200 walk guide example (2015). Printed copies of a four-page guide (8.5" x 11" when folded) were distributed for each thematic module. Students were encouraged to sketch and take notes on their copies, and expected to insert replies to specific prompts in the blank spaces on pages three and four. Essay reflection prompts were placed at the end of the last page.

Source: authors

In addition to leading students through the streets, the walk guide presented basic facts about features of the streetscape and routinely asked students to pause and consider their environment and experiences in relation to the module's theme. The walk guide included spaces for students to take notes and sketch in response to queries or as they deemed necessary en route, thus rendering the document a personalized record of one's observations and thought processes, as well as a useful tool for later review (Figure 6). 


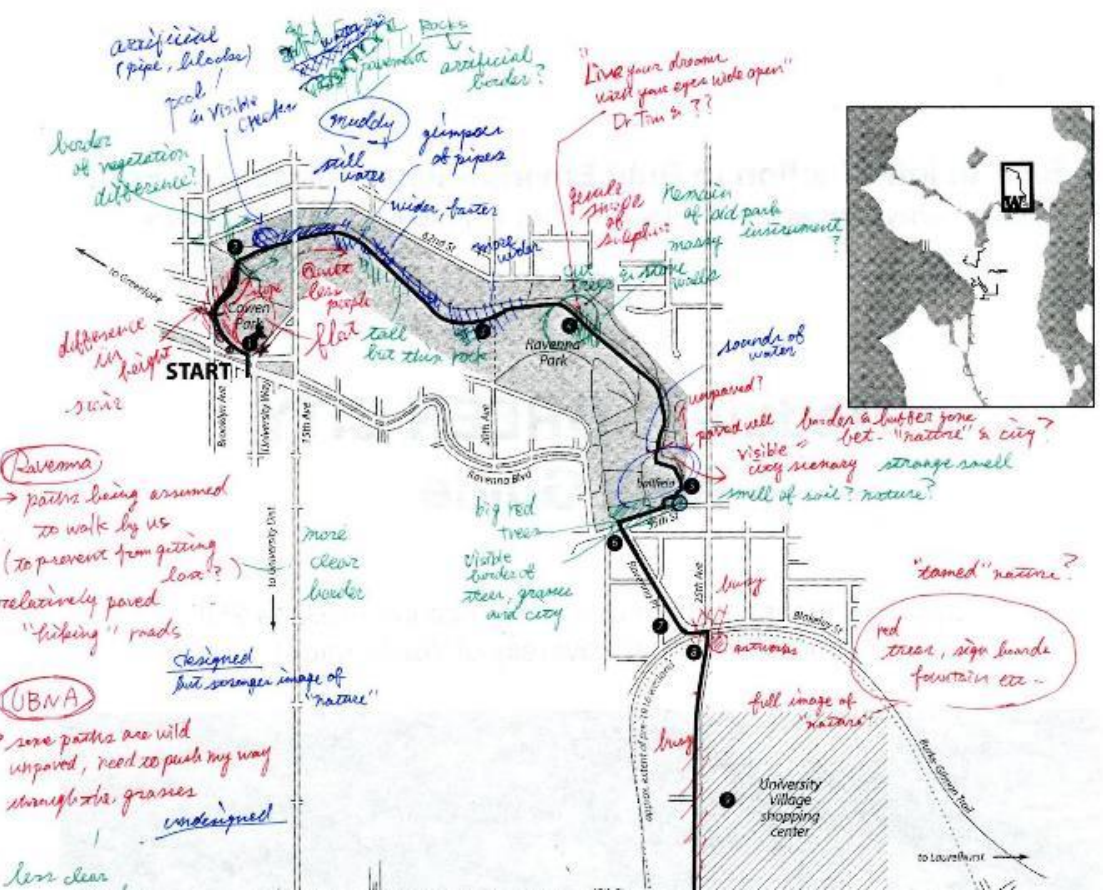

Figure 6. BE200 "Green City" walk guide with student's notation (2015, detail). Participants were encouraged to actively take notes while walking in order to record their personal experiences and impressions.

Source: authors and a BE200 student

For example, while walking through Seattle's Ravenna neighborhood during the Green City module, participants were asked to pause, observe, and note thoughts on the effectiveness of a sidewalk art installation intended to raise awareness of a rerouted and partially restored waterway. By discouraging the use of 'smart phone' navigation aids and inviting students to rely as much as possible on the printed walk guide, instructors sought to encourage maximum multi-sensory engagement with the dynamic built environment. That said, facilitators invited participants to photograph the built environment during their walks, not to simply document sites and collect information, but to generate personal "creative encounters" through a medium popular among today's youth. ${ }^{53}$ Each walk guide concluded with a more substantial essay prompt intended to facilitate critical analysis, self-reflection, and synthesis of lecture materials, assigned readings,

\footnotetext{
${ }^{53}$ Noora Pyyry, "Learning with the City Via Enchantment: Photo-walks as Creative Encounters," Discourse: Studies in the Cultural Politics of Education 37 no. 1 (2016): 111. A unique course 'hashtag' label (\#UWbe200) was created to facilitate the posting and collection of images on Instagram in order to allow instructors and other students to explore them.
} 
and walk experiences. These more synthetic questions tasked students with, for example, considering the validity of the conventional city/nature binary or assessing competing interests of downtown public space management. Participants completed each short response essay, the maximum length of which was 500 words, in advance of each module's final session-the small group discussion.

"Conversational learning" was achieved through regular small group discussion sessions, ${ }^{54}$ during which students were invited to report on their walk experiences and discuss sites and moments they considered relevant to the module's theme. ${ }^{55}$ Activities, including thought exercises, sketching, and brainstorming sessions, followed and drew upon walks, as well as module lectures and previously assigned readings. These relatively informal meetings also provided opportunities for the reinforcement of particularly salient issues while cultivating a sense of community among students whose participation fueled the sessions. In order to further inspire conversations during these hour-long periods, a second set of readings was assigned for each session (see Figure 3). Generally shorter than earlier pieces read prior to lectures, these texts were typically chosen to underscore the modules' themes and facilitate connections between Seattle and cities elsewhere. They were often site-specific or focused thematically. For example, the Historic City module included texts on Seattle's evolving preservation movement, and for the discussion session, a more theoretical text on gentrification. ${ }^{56}$ During that particular session, students were tasked with adopting the roles of different constituents for a staged debate on plans to demolish an 1920s-era building to make way for a luxury apartment complex-a regular occurrence in today's Seattle (see Figure 2). The instructional scaffolding for each module thus

\footnotetext{
${ }^{54}$ Effective "conversational learning" requires spaces that "integrate thinking and feeling, talking and listening, leadership and solidarity, recognition of individuality and relatedness, and discursive and recursive processes." See Kolb, Experiential, 298.

55 These sessions typically began with a brief discussion of several more provocative Instagram postings, which proved to be an effective conversation 'jump-start.'

56 Japonica Brown-Saracino, "What is Gentrification? Definitions and Key Concepts," in The Gentrification Debates (New York: Routledge, 2010), 11-18.
} 
included lectures, texts, walks, and discussions, providing reflective opportunities for critical thinking and communication through reading, listening, writing, and talking. The cumulative effect of this was intended to maximize exposure to course content, relevant literature, and real spaces, while fostering learning at three social scales-whole-class (lectures), small-group (discussion sessions), and individual (walks, reading, writing).

Several of the activities described above provided opportunities for performance assessment. In addition to the short reflection essays, instructors evaluated general participation in small group discussion sessions, during which participants submitted their walk guides. Instructors assessed students' level of engagement through written notes and sketches on their personalized walk guides and learned that the vast majority of participants completed walks and demonstrated critical engagement. ${ }^{57}$ Finally, two exams were given during the ten-week term, each of which was multiple-choice and drew upon the totality of assigned readings, lectures, and walk guide content. Course grades were thus based upon a variety of performance types that required not only data retention, but also critical thinking and creative response generation in several reflective modes.

\section{Conclusion: Facilitating Lifelong Learning in Built Environments}

The BE200 approach, with its pedagogical emphasis on pre-disciplinarity, experiential and place-based learning, and instructional scaffolding organized in successive action-reflection cycles, substantially enhanced students' engagement with course themes, Seattle, themselves and each other. Profoundly, some students cultivated new perspectives that in several cases prompted an ontological shift in their understanding and approaches to the built environment in their everyday lives. The course "made me think about my environment in a new way and be more

\footnotetext{
$5785.3 \%$ of individual walks were completed, based on the number of walk guides submitted by students.
} 
reflective in my observations," said one student in their post-course anonymous evaluation (Figure 7).

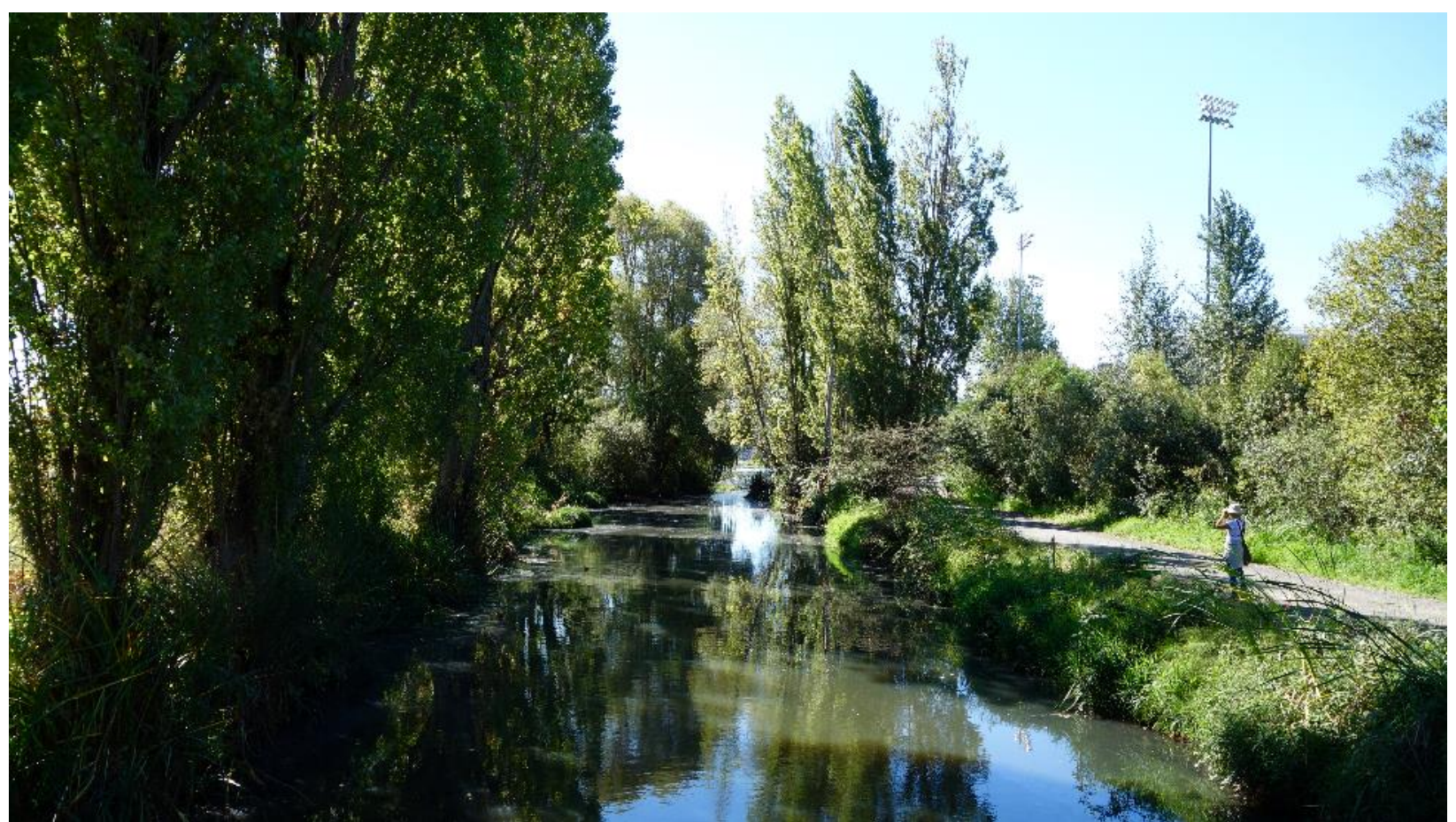

Figure 7. Union Bay Natural Area, Seattle (2015). Students explored the area during the "Green City" walk. Many expressed surprise in finding that such 'natural' spaces exist in the city and have been so significantly modified by human intervention.

Source: Daniel E. Coslett

"Now, when I walk through these neighborhoods I am aware of the changes in the built environment and the history behind it," said another. Similarly, another reported that, "Before taking this class, I've [sic] never thought about how our built environment has changed. It really motivated me to think critically."

BE200 addressed the needs and concerns of various allied stakeholders. For its BE PhD program student-instructors, the class was a unique (and rare) opportunity to fully conceive, develop, and teach a course that reflects the innovative approach of their academic program, staking a claim for the importance of built environments study outside the bounds of traditional disciplinary silos. Though individual instructors took turns serving as module leaders, all members of the instruction team contributed to the crafting of each thematic module. Discussing content, 
sharing lecture and reading notes, and designing walks and walk guides collectively as active participants in the entire course development and implementation process, members fostered a genuine culture of collaboration within a mutually supportive and invested cohort. In fact, the entire BE200 process functioned as an enriching experiential learning moment of its own, in the mode of Joplin, with its course development, course implementation, and this reflective essay functioning as a complete (and repeatable) action-reflection cycle with its focus, action, and debrief stages. For the CBE, this kind of course remains attractive as a means for recruiting students into the College's various programs, and in that regard BE200 appears to have been successful. ${ }^{58}$ For the larger University, it can serve as a facilitator of local place attachmentparticularly important for retention in large campus settings where many incoming students can feel overwhelmed or homesick. For example, the new awareness of one's urban surroundings prompted by the course inspired a change in one student's self-identity: "After taking this course, I feel like I can more accurately call myself a Seattleite."

The success of BE200-which is now to be a permanent, but flexible, feature of the UW CBE curriculum—need not be limited to its current form and context. Indeed, BE200 will change as its team of facilitators evolves and brings new interests and expertise to the process, and its broad themes and walk routes will change as Seattle does. A class like this could certainly work in other urban contexts, however. While Seattle offers a great deal due to the dynamic nature of its current state, all places can contribute to the holistic education of built environments students. Critical observation and careful course planning can expose salient themes elsewhere, and their framing through inter- or pre-disciplinary lenses can introduce students to broadly relevant issues embodied by specific locales. Place-based and immersive methods can be useful anywhere because, as Gruenewald says, "What we know is, in large part, shaped by the kinds of places we

\footnotetext{
${ }^{58} \mathrm{~A}$ majority of surveyed students $(72 \%)$ reported in their post-course evaluations that they would consider taking future courses offered by CBE departments.
} 
experience and the quality of attention we give them." ${ }^{59}$ Not only are the benefits numerous, but the approach is timely, as "teaching about place is especially relevant in the increasingly mediated educational environments of the twenty-first century." ${ }^{60}$ Whereas none of the strategies deployed in BE200 are without precedent, and certainly "nomadic" and place-based courses have been executed, ${ }^{61}$ the particular way in which BE200 was structured and its content framed and delivered can serve as a flexible model for educators seeking to implement courses and/or curricula that introduce students to the built environment prior to incorporating them into traditional disciplinary frameworks.

BE200 aims for more than just the general comprehension and retention of course content; rather, most pertinent for introductory built environment educational contexts, it promotes the synthesis and modes of learning that many students will encounter in discipline-specific curricula. The potential of BE200 and classes like it is far greater, however, than merely training a generation of competent built environments designers and specialists capable of collaborative and socially impactful practice. For professionals, but also for those who engage with the built environment only through lived experiences, there is a broader social value to perceiving cities as both incomprehensibly and unpredictably complex and the product of collective, human agency. The course's focused learning experiences enhance thoughtful observation and active interaction with the real world, thereby cultivating broad-thinking, critically inquisitive, and empathetic citizens-indeed, traits relevant for both professionals and citizens at large, all of

\footnotetext{
59 Gruenewald, “Foundations," 645.

60 Laird Christensen and Hal Crimmel, "Introduction," in Teaching About Place, eds. Laird Christensen and Hal Crimmel (Reno: University of Nevada, 2008), xi.

61 Thomas Fisher, "My Nomadic Class," Chronicle of Higher Education, 15 April 2015, accessed 10 May 2016, http://chronicle.com/blogs/conversation/2015/04/15/my-nomadic-class/ presents a good example of another mobile course wherein the university campus inspired new ways of thinking and acted as a "memory palace." Laird Christensen and Hal Crimmel, eds., Teaching About Place (Reno: University of Nevada, 2008) includes case studies of many immersive, interdisciplinary, place-based courses for adults and young adults. Perambulatory learning for youths (aged 5-12) that emphasizes the integrated nature of built environments and fosters the development of informed attitudes has been addressed by Elizabeth Curtis, "Walking Out of the Classroom: Learning on the Streets of Aberdeen," in Ways of Walking, eds. Tim Ingold and Jo Lee Vergunst (Burlington, VT: Ashgate, 2008), 143-54.
} 
whom could benefit from enhanced lifelong learning attributes related to the built environment. Professionals may come to optimally address the increasingly complex challenges facing the globe; but more fundamentally individuals, cognizant of their own personal agency, may come to see themselves as members of a larger creative community engaged in the creation, use, and management of the constructed environment. By "facilitating integrated development in affective, perceptual, cognitive, and behavioral realms" the experiential aspects of the course have the potential to do more than just effectively educate future architects and planners in their disciplinary realms. ${ }^{62}$ Indeed, "Educating the whole person means that the goal of education is not solely cognitive knowledge of the facts, but also includes development of social and emotional maturity." ${ }^{63}$ In its exploration of the deeper meaning of ideas and reevaluation of assumptions underlying them, the BE200 model contributes to the training of observant and engaged citizens who both think and act critically, thus ultimately attending to the ever-relevant, aspirational mission of higher education.

\section{Acknowledgment}

The authors would like to acknowledge the support of John Schaufelberger (UW CBE Dean) and Bob Mugerauer (BE PhD program director) during the process of establishing BE200. Very special thanks go to Prof. Vikramāditya Prakāsh (UW) and Naeun Gu (BE PhD candidate) for their enthusiastic and dedicated participation in the course conception and teaching processes. For their constructive feedback on earlier versions of this essay, the authors are furthermore grateful to Vikramāditya Prakāsh, Naeun Gu, and to Tammy Tasker (Western Washington University) for her helpful suggestions regarding education issues engaged in the article. The feedback of two anonymous peer-reviewers is appreciated, as well.

62 Kolb, Experiential, 300.

63 Ibid. 


\section{References}

Anderson, Sean. "How Architecture Can Redefine the Migrant Crisis." CNN Style, 18 May 2016. Accessed 18 May 2016, http://edition.cnn.com/2016/05/18/architecture/sean-anderson-momarefugee-architecture/index.html.

Andraos, Amale. "What Does Climate Change (for Architecture)?" In Climates: Architecture and the Planetary Imaginary, edited by James Graham, 297-301. New York: Columbia University/Lars Müller, 2016.

Anon. "The Digital Campus: Tech Innovators 2016." Chronicle of Higher Education. Accessed 10 May 2016. http://chronicle.com/specialreport/The-Digital-Campus-Tech/35.

Baldasty, Gerald J., and Marisa Nickle, eds., "Innovators Among Us: When Technology Brings Learning to Life." Accessed 10 April 2016. http://www.washington.edu/trends/innovators-amongus-when-technology-brings-learning-to-life/.

Balk, Gene. "Census Data: Seattle Aaw Steepest Rent Hike Among Major U.S. Cities." Seattle Times, 18 September 2014. Accessed 10 May 2016. http://www.seattletimes.com/seattlenews/data/census-seattle-saw-steepest-rent-hike-among-major-u-s-cities/.

- - -. "Seattle No Longer America's Fastest-growing Big City." Seattle Times, 21 May 2015. Accessed 10 May 2016. http://www.seattletimes.com/seattle-news/data/seattle-no-longeramericas-fastest-growing-big-city/.

- - -. "Seattle's Population Boom Approaching Gold Rush Numbers." Seattle Times, 13 September 2015. Accessed 10 May 2016. http://www.seattletimes.com/seattlenews/data/seattles-population-boom-approaching-gold-rush-numbers/.

Baudelaire, Charles. "The Painter of Modern Life," Le Figaro, 1863.

Brown-Saracino, Japonica. "What is Gentrification? Definitions and Key Concepts." In The Gentrification Debates, 11-18. New York: Routledge, 2010.

Christensen, Laird, and Hal Crimmel, eds. Teaching About Place. Reno: University of Nevada, 2008.

Curtis, Elizabeth. "Walking Out of the Classroom: Learning on the Streets of Aberdeen." In Ways of Walking, edited by Tim Ingold and Jo Lee Vergunst, 143-54. Burlington, VT: Ashgate, 2008.

de Certeau, Michel. The Practice of Everyday Life, translated by Steven Rendall. Berkeley, CA: University of California, 1984.

DeMillo, Richard. Revolution in Higher Education. Cambridge, MA: MIT, 2015.

Dober, Richard P. Environmental Design. Huntington, NY: Robert E. Krieger, 1975.

Fink, L. Dee. Creating Significant Learning Experiences. San Francisco: Jossey-Bass, 2013. 
Finley, Todd. “Are Learning Styles Real-and Useful?" Edutopia, 22 September 2015. Accessed 31 May 2016. http://www.edutopia.org/article/learning-styles-real-and-useful-toddfinley.

Fisher, Thomas. "My Nomadic Class." Chronicle of Higher Education, 15 April 2015. Accessed 10 May 2016. http://chronicle.com/blogs/conversation/2015/04/15/my-nomadic-class/

Gardner, Howard. Frames of Mind: The Theory of Multiple Intelligences. New York: Basic, 1983.

Gardner, Howard, and Veronica Boix Mansilla. "Teaching for Understanding in the Disciplines and Beyond." Teachers College Record 96 no. 2 (1994): 198-218.

Golde, Chris. "Teaching Development for All Doctoral Students: It's Time." Grad Logic, 19 April 2016. Accessed 20 June 2016. http://gradlogic.org/lsfss/.

Graff, Harvey J. Undisciplining Knowledge: Interdisciplinarity in the Twentieth Century. Baltimore, MD: Johns Hopkins University, 2015.

Gruenewald, David A. "Foundations of Place: A Multi-disciplinary Framework for Placeconscious Education." American Educational Research Journal 40 no. 3 (2003): 619-54.

Hong, Yi-Chun, and Ikseon Choi. "Three Dimensions of Reflective Thinking in Solving Design Problems: A Conceptual Model." Educational Technology Research and Development 59 (2011): 687-710.

Hou, Jeff. Insurgent Public Space: Guerilla Urbanism and the Remaking of Contemporary Cities. New York: Routledge, 2010.

Jacks, Ben. "Reimagining Walking: Four Practices." Journal of Architectural Education 57 no. 3 (2004): 5-9.

Jacobs, Jerry. "Interdisciplinary Hype." Chronicle of Higher Education, 22 November 2009. Accessed 10 May 2016. http://chronicle.com/article/Interdisciplinary-Hype/49191/.

Jaschik, Scott. "Undisciplining Knowledge." Inside Higher Ed, 10 September 2015. Accessed 11 May 2016. https://www.insidehighered.com/news/2015/09/10/author-discusses-new-bookinterdisciplinarity.

Joplin, Laura. “On Defining Experiential Education.” Journal of Experiential Education 4 no. 1 (1981): 17-20.

Kelly, Sean, and Julianne Turner. "Rethinking the Effects of Classroom Activity Structure on the Engagement of Low-achieving Students." Teachers College Record 111 no. 7 (2009): 1665-92.

Kolb, David A. Experiential Learning: Experience as the Source of Learning and Development. Upper Saddle River, NJ: Pearson, 2015.

Landscape Architecture Accreditation Board. Accreditation Standards. 2016. Accessed 10 May 2016. 
https://www.asla.org/uploadedFiles/CMS/Education/Accreditation/LAAB_ACCREDITATION_ST ANDARDS_March2016.pdf.

Levine, Daniel U. "Experiencing the City." Journal of Experiential Education 1 no. 2 (1978): 1319.

Lynch, Kevin. The Image of the City. Cambridge: MIT, 1960.

Matheson, Catherine. "The Educational Value and Effectiveness of Lectures." The Clinical Teacher 5 (2008): 218-21.

Middleton, Jennie. "Sense and the City: Exploring the Embodied Geographies of Urban Walking." Social \& Cultural Geography 11 no. 6 (2010): 575-96.

Miller, Peter. "Is 'Design Thinking' the New Liberal Arts?" Chronicle of Higher Education. 26 March 2015. Accessed 2 June 2016, http://chronicle.com/article/ls-Design-Thinking-theNew/228779/.

National Architectural Accrediting Board. 2014 Conditions for Accreditation. 2014. Accessed 10 May 2016.

http://www.naab.org/f/documents/streamfile.aspx?sortfield=lastmodifiedlasc\&name=01_Final+A pproved $+2014+\mathrm{NAAB}+$ Conditions+for+Accreditation. pdf\&path=Public+Documents $\% 5 \mathrm{CNAAB}+$ News\%5C.

National Council of Teachers of English. "Position Statement on Interdisciplinary Learning, PreK to Grade 4." 14 August 2008. Accessed 10 May 2016.

http://www.ncte.org/positions/statements/interdisclearnprek4.

Oldenberg, Ray. The Great Good Place. Cambridge, MA: Da Capo, 1999.

Phillips, S.D., and T.McL. Semple. "Environmental Dispositions and the Education of Environmental Specialists: A University Case Study." In New Directions in Environmental Design (vol. 2), edited by Walter Rogers and William Ittelson, 480-88. Washington, D.C.: Environmental Design Research Association, 1978.

Planning Accreditation Board. Accreditation Standards and Criteria. 2012. Accessed 10 May 2016. http://www.planningaccreditationboard.org/.

Pyyry, Noora. "Learning with the City Via Enchantment: Photo-walks as Creative Encounters." Discourse: Studies in the Cultural Politics of Education 37 no. 1 (2016): 102-15.

Romano, Tricia. "Cultures Clash as Gentrification Engulfs Capitol Hill." Seattle Times, 13 March 2015. Accessed 22 April 2016. http://www.seattletimes.com/life/lifestyle/culture-clash-on-capitolhill/.

Rybczynski, Witold. "Revisiting Rem Koolhaas's Central Library and Peter Bohlin's City Hall in Seattle." Architect, April 2013. Accessed 27 April 2016.

http://www.architectmagazine.com/design/revisiting-rem-koolhaass-centrallibrary-and-peterbohlins-city-hall-in-seattle_o. 
Sandercock, Leonie. Towards Cosmopolis: Planning for Multicultural Cities. New York: Wiley, 1998.

Schema Design. "Changing Seattle: Tracking Demolition Permits." Arcade 33 no. 2, 13 October 2015. Accessed 10 May 2016. http://arcadenw.org/article/changing-seattle.

Smith, Gregory A. "Place-based Education: Learning To Be Where We Are." Phi Delta Kappan 83 (2003): 584-94.

Sweeney, Michael. "Who Designs the Built Environment? A Model for Public Awareness in Environmental Design." In New Directions in Environmental Design (vol. 2), edited by Walter Rogers and William Ittelson, 499-510. Washington, D.C.: Environmental Design Research Association, 1978.

Taylor, Mark. "End the University as We Know it." New York Times, 26 April 2009. Accessed 10 May 2016. http://www.nytimes.com/2009/04/27/opinion/27taylor.html.

Toyama, Kentaro. "Why Technology Will Never Fix Education." Chronicle of Higher Education, 19 May 2015. Accessed 10 May 2016. http://chronicle.com/article/Why-Technology-Will-NeverFix/230185/.

University of Washington College of Built Environments. "BE PhD." Accessed 22 April 2016. http://be.washington.edu/phd/.

University of Washington College of Built Environments. "Labs + Centers." Accessed 9 May 2016. http://www.be.washington.edu/research/labs-and-centers/.

University of Washington Office of Planning and Budgeting. "Activity Based Budgeting." Accessed 22 April 2016. http://opb.washington.edu/activity-based-budgeting.

Walther, Joachim, Shari E. Miller, and Nadi N. Kellam. "Exploring the Role of Empathy in Engineering Communication Through a Transdisciplinary Dialogue." Paper presented at the American Society for Engineering Education Annual Conference, San Antonio, Texas, June 1013, 2012. Accessed 10 May 2016.

https://www.asee.org/public/conferences/8/papers/4670/view.

Wineburg, Samuel S., Pamela L. Grossman, and Scott F. Beers. "Introduction: When Theory Meets Practice in the World of School." In Interdisciplinary Curriculum: Challenges to Implementation, edited by Samuel S. Wineburg and Pamela L. Grossman, 1-16. New York: Teachers College, 2000.

Wunderlich, Filipa. "Walking and Rhythmicity: Sensing Urban Space." Journal of Urban Design 13 no. 1 (2008): 125-39. 